\title{
A study of antimicrobial activities of aqueous and ethanolic extract of bee pollen against
}

Kasim Roba Jilo ( $\sim$ kasimroba7@gmail.com )

Holeta bee research center

\section{Research}

Keywords: Antimicrobial activities, aqueous extract, bee pollen, ethanol extract

Posted Date: August 23rd, 2021

DOI: https://doi.org/10.21203/rs.3.rs-819311/v1

License: (c) (1) This work is licensed under a Creative Commons Attribution 4.0 International License. Read Full License 


\section{Abstract \\ Background}

Ethiopia is one of the plant species-rich countries in the world and the center of origin of many medicinal plants. Studying antimicrobial activities of pollen is vivacious to investigate plant resources for medicinal values and the study was conducted to evaluate antimicrobial properties of bee pollen against mentioned bacteria.

\section{Methods}

Completely Randomized Design was used for laboratory work. After adjusting turbidity, consistent growth of bacterial culture was made using a sterilized cotton swab. 20 grams of bee pollen was added to 200 $\mathrm{ml}$ of distilled water as well as ethanol and finally, the extract was filtered by Whatman filter by paper, dried and weighted and stock solutions were made as follows, $3.6 \mathrm{gm}$. was added to $12 \mathrm{ml}$ of distilled water to prepare stock solutions as follows 3.6:12 $=0.3 \times 10^{6}=3 \times 10^{5} \mathrm{ppm}$ stock solution and antimicrobial activities of pollen were tested against mentioned bacteria. Data were imported to $R$ software version 3.44. Multilevel analysis was used to see the interaction between bacteria species and each concentration of pollen and Anova was used to see the significance of these concentrations on bacteria species. A p-value of $<0.05$ was considered statistically significant.

\section{Results}

Results indicated that bacteria were more inhibited at 72 hours than 48 and 24 hours and the results showed an ethanolic extract of bee pollen had antimicrobial activities against both Gram-negative and Gram-positive bacteria mentioned above. Time has significant effects on tested bacteria $(p=0.000)$ and treatments have significant effects on tested organisms $(p=0.000)$. The ethanolic extract inhibited the growth of more Gram-negative bacteria: Escherichia coli and Shigella boydii. Bacillus subtilis was mostly inhibited by aqueous extract of bee pollen than others.

\section{Conclusions}

Ethanolic extract of pollen had antibacterial activities against all tested bacterial strains even though it is concentration and time-based. The ethanolic extract inhibited more Gram-negative bacteria relatively while aqueous extract inhibited more Gram-positive relatively. Negative controls (sterilized water) didn't show any antimicrobial properties, while positive control (Chloramphenicol) had antimicrobial activities. Further isolation and characterization of bioactive compounds from pollen are useful to develop a novel botanical formulation for further applications from the pollen of medicinal plants. 


\section{Plain English Summary}

Researchers have explored different types of working concentrations to evaluate aqueous and ethanolic extract of bee pollen against Escherichia coli, Shigella boydii, Staphylococcus aureus, and Bacillus subtilis. Antimicrobial activities of the extract depending on exposure period and working concentrations. Different bacteria species have their resistance against the concentrations. These days many bacteria are developing resistance against prescribed bacteria species and the alternative we do have is studying and finding solutions from different plant products like pollen and others. Ethanolic extract of pollen had antibacterial activities against all tested bacterial strains even though it is concentration and time-based. The ethanolic extract inhibited more Gram-negative bacteria relatively while aqueous extract inhibited more Gram-positive relatively since extract of a bioactive compound depends on the solvent used for extractions. Research suggests that studying antimicrobial activities of pollen extract of aqueous and ethanol may help to understand better solvent for active compound extraction that inhibits more bacteria. I realize that future studies may develop novel drugs for bacteria already developed against prescribed drugs. This paper describes aqueous and ethanolic extract bee pollen against mentioned bacteria. Lastly, experiences from the research team, lessons learned, and a personal statement from the person with lived experience are provided to help future researchers for novel bioactive formulations. The online discussions will be used in future research prioritization processes. Standardized reporting of this study will help inform the future involvement of participants studying antimicrobial activities of different solvent extracts.

\section{Introduction}

Ethiopia is one of the plant species-rich countries in the world and the center of origin of many medicinal plants. Many naturally occurring compounds present in plants, herbs, and spices have been shown to possess antimicrobial effects against foodborne pathogens and the production of bee pollen might help to increase economic profits and thus help beekeepers to rectify their financial difficulties(1). Bee pollen is promoted as a healthy food with a wide range of nutritional and therapeutic properties(14). Human societies have been in close contact with their environments since the beginning of their formation and used the ingredients of the environment to obtain food and medicine(3). An interest in substances of natural origin has been a subject that is increasing constantly-both those known for many years and recently discovered are of great interest to the researchers and this interest also applies to bee products because of their extensive nutritional and therapeutic properties; these products are known and used for several thousand years, but only recently, they became the subject of sparse documented scientific research and Greeks believed that honey and pollen are the food of kings, giving the youth and life(4). Pollen, another bee product, is recognized as an important part of traditional medicine in several countries; because of its nutritional and therapeutic properties, pollen is considered a functional food in the food industry because of phenolic compounds such as gallic, caffeic, and trans-cinnamic acid are the components of pollen that are responsible for antibacterial and antioxidative effects(5). Bee-collected pollen is a well-known functional food, Honey bees process the collected pollen and store it in the hive, Loading [MathJax]/jax/output/CommonHTML/jax.js en is called bee- bread or ambrosia and it is the main source 
of proteins, lipids, vitamins, macro-and micro-elements in honey bee nutrition and nowadays there is increasing interest regarding honeybee products, their bioactivity, and implementation in alternative medicine and apitherapy(6). The use of natural products is becoming an ever more popular approach in both medical treatments and the preservation of foods(7). Bee pollen is consumed for API-therapeutical, nutritional and medicinal properties, and its actions are attributed to its chemical composition and mostly phenolics, carotenoids, fatty acids, and vitamins(8). Among the bee products, bee pollen resulting from the agglutination of flower pollen and nectar with salivary substances, emerge as food for worker-bees, with therapeutic properties given its composition(9). Bee pollens are a rich source of essential amino acids and are often considered as a complete food for human beings and Apitherapy has become popular as an alternative treatment in recent years and pharmaceutical properties of bee products depend on biological activities such as antioxidant and antibacterial activities(10). Bee-collected pollen and beebread are appreciated mainly for their high nutritional value. Both products are rich in proteins, essential amino acids, sugars, fatty acids (including $\omega-3$ and $\omega-6$ fatty acids), vitamins, macro, and microelements(6). Pollen is a product harvested by bees and the pollen transferred to the hive in the form of pollen loads is called the "bee pollen" it is the product that contains valuable substances such as essential amino acids, phenolic compounds, vitamins, pigments (11). Pollen, another bee product, is recognized as an important part of traditional medicine in several countries. Because of its nutritional and therapeutic properties, pollen is considered a functional food in the food industry(5). Bee pollen is a food supplement widely used in the world due to the benefits promoted by the bioactive compounds present in it (12). Biologically active substances of natural origin always focus a great interest. This also applies to bee products because of their powerful healing properties and Bees' life is still the subject of scientific interest and a source of inspiration for artists, and the bees remain the symbol of diligence and thrift(4). Natural products can be utilized in the discovery of new antimicrobial drugs and in the treatment of infectious diseases(7).

\section{Material And Methods:}

\section{Sample size and design of the experiment}

The experimental design was a Completely Randomized Design for the laboratory (CRD). Three working concentrations were used for the experiment and replicated thrice for these bacteria species at exposure experimental periods 24,48 and 72 hours.

Description of the study area and location of the study area

The study was conducted at Hawassa University Biology laboratory which is found in Hawassa is a city in Ethiopia, which is found on the shores of Lake Hawassa in the Valley. It is located $273 \mathrm{~km}$ south of Addis Ababa. It has latitude and longitude of $7^{\circ} 3^{\prime} \mathrm{N} 38^{\circ} 28^{\prime} \mathrm{E} 7^{\circ} 3^{\prime} \mathrm{N} 38^{\circ} 28^{\prime} \mathrm{E}$ and an elevation of 1708 meters above sea level. Hawassa has a tropical savanna climate though it borders on a subtropical highland climate www.hu.edu.et Background of Hawassa University October 2, 2013. 


\section{Solvent extractions of pollen samples and preparation of working concentrations}

Different amounts of bee pollen were milled, homogenized, and individually extracted $20 \mathrm{gm}$. of bee collected pollen with aqueous and ethanol was added to $250 \mathrm{ml}$ of beakers that contains $200 \mathrm{ml}$ of distilled water and shacked for 24 hours and filtered by Whatman filter paper and then dried in the water bath. The extracts of pollen were measured by sensitive balance and then stock solutions and working concentrations were prepared the resulting solutions were stored at $4{ }^{\circ} \mathrm{C}$ until antibacterial activity determination(8). Twenty gram of bee pollen was added to $200 \mathrm{ml}$ of ethanol (70\%), shacked for twentyfour hours, and filtered by Whatman filter paper, and dried in a water bath at $78^{\circ} \mathrm{C}$ stayed in a water bath $70^{\circ} \mathrm{C}$, for $30 \mathrm{~min}(5)$. The extracts of pollen were measured by sensitive balance and then stock solutions and working concentrations were prepared as follows $3.6 \mathrm{gm}$. of extracts was added to $12 \mathrm{ml}$ of distilled water and calculated as 3.6:12 $=0.3 \times 10^{6}=3 \times 10^{5} \mathrm{ppm}$ stock solution and then working concentrations of $100 \%, 70 \%$, and $30 \%$ were prepared from a stock solution prepared. The resulting solutions were stored at $4{ }^{\circ} \mathrm{C}$ until antibacterial activity determination(10).

\section{Inoculum Preparation and inoculation of bacteria strains in laboratory}

Four species of bacteria were selected; two Gram-positive: Staphylococcus aureus and Bacillus subtilis. two-Gram negative: Escherichia coli and Shigella boydii and were cultured. With the help of a sterile wire loop, the test bacteria were transferred into test tubes having a sterile nutrient broth and incubated at $37^{\circ} \mathrm{C}$ for 24 hours until the noticeable turbidity and density was equal to that of $0.5 \mathrm{McF}$ arland standards by adding $0.5 \mathrm{ml}$ of $\mathrm{BaCl}_{2}$ solution into $99.5 \mathrm{ml}$ of $\mathrm{H}_{2} \mathrm{SO}_{4}$. After adjusting turbidity, a sterile cotton swab was dipped into suspension and streaked over the whole surface of the plate to make sure the consistent growth of bacterial culture (13).

The antibacterial efficacy of these products against pathogenic Gram-Positive bacteria. (B. Subtilis, S. Aureus ) and Gram-negative bacteria ( S. boydii and E. coli ) by Ditch Diffusion Method

Four species of bacteria were selected for the experiment; two Gram-positive: Staphylococcus aureus and Bacillus subtilis(14). Two-Gram negative: Escherichia coli and Shigella boydii and were cultured. As well, nectar was used directly in all concentrations since no need for extraction nectar. Antimicrobial activities of pollen were tested against mentioned bacteria after they were incubated. Disks were mixed into working concentrations of $100 \%, 70 \%$, and $30 \%$ and then added to labeled bacteria species inoculated into Petri dish respectively and stayed for 10-15 minutes until introduced with media, inverted, and brought to incubator incubated at $37 \otimes \mathrm{C}$. The inhibition zone of bacteria was checked continuously for 24,48 , and 72 hours and measured at 48 and $72 \mathrm{hrs}$. The antibiotic was placed aseptically in the middle of the plate and was incubated at $37^{\circ} \mathrm{C}$ for $24 \mathrm{~h}$. The inhibitory zone diameter was measured in $\mathrm{mm}(10)$.

\section{Data analysis}

Loading [MathJax]/jax/output/CommonHTML/jax.js 
Pollen was collected and dried at the laboratory and then grinded and tested against mentioned bacteria and data were inserted to computer Microsoft excel 2010 and imported to R software version 3.44.

Multilevel analysis was used to see an interaction between bacteria species and each concentration and Anova was used to see the significance of these concentrations on bacteria species. A p-value of $<0.05$ was considered as statistically

\section{Results}

Table 1

Mean \pm standard deviation of inhibitions zone of bacteria by tested products after $48 \mathrm{hrs}$

\begin{tabular}{|lllll|}
\hline Tested products at $\mathbf{t} 1$ & E. coli & S. boydii & S. aureus & B. subtilis \\
\hline Drug (positive) control & $8.46 \pm 0.51$ & $6.91 \pm 0.22$ & $\begin{array}{l}17.63 \pm \\
0.49\end{array}$ & $20.49 \pm 0.49$ \\
\hline Pp30\%w & $1.72 \pm 0.28$ & $1.63 \pm 0.39$ & $2.13 \pm 0.93$ & $1.47 \pm 1.53$ \\
\hline Pp70\%w & $9.27 \pm 3.13$ & $10.31 \pm$ & $9.13 \pm 1.91$ & $9.22 \pm 3.03$ \\
\hline Pp100\%w & $13.05 \pm$ & $11.84 \pm$ & $11.14 \pm$ & $11.69 \pm 4.18$ \\
\hline Pp30\%E & 3.42 & 4.24 & 3.53 & \\
\hline Pp70\%E & $1.57 \pm 0.47$ & $1.65 \pm 0.47$ & $2.05 \pm 0.08$ & $1.87 \pm 0.89$ \\
\hline Pp100\%E & $10.43 \pm$ & $9.54 \pm 1.73$ & $9.09 \pm 2.84$ & $10.5 \pm 3.71$ \\
\hline $\begin{array}{l}\text { Sterilized water. water(negative) } \\
\text { control) }\end{array}$ & 2.96 & & & $11.75 \pm 4.77$ \\
\hline Values aremean & $13.61 \pm$ & $13.18 \pm$ & $11.66 \pm$ & \\
\hline
\end{tabular}

Values are mean \pm standard deviation of three replications of these concentrations of the extract

In the study, it is observed that when the same concentration of the two solutions of poly pollen, against four bacteria a different mean of inhibition zone, is observed. Among two solutions of poly pollen water extract solution with $100 \%$ concentration with the mean inhibition zone of $13.05 \pm 3.42,11.84 \pm 4.24$, $11.14 \pm 3.53,11.69 \pm 4.18$ against $E$. coli, $S$. boydii, $S$. aureus, and $B$. subtilis respectively. Time has highly significant effects on all species of bacteria on both Gram-negative and Gram-positive bacteria (Table 1). This means inhibitions zones of bacteria depend on exposure periods that at 24 hours it might be less inhibition, but at 48 and 72 hours, there may be more inhibition. In this study, the inhibition zones were measured against the test bacteria at 48- and 72-hours' time intervals. Almost all the solutions with three different concentrations (30\%, $70 \%$, and $100 \%$ ) produce a higher inhibition zone after 72 hours exposure than 48 hours exposure. The $30 \%$ concentration poly pollen ethanol extract also showed the lower $(1.83 \pm$ 0.68 ) result at the time of 72 hours than 48 hours $(2.05 \pm 0.08)$ against $S$. aureus. In the study the 
the time of 72 hours, this might be due to the reaction of bioactive compounds found in the solution of poly pollen.

Table 2

Mean \pm standard deviation of inhibitions zone of bacteria by tested products after 72 hrs exposure periods

\begin{tabular}{|lllll|}
\hline Tested products at $\mathbf{2} 2$ & \multicolumn{4}{l}{ Bacterial isolates } \\
\cline { 2 - 5 } & E. coli & Boydii & S. aureus & B. subtilis \\
\hline Drug & $13.41 \pm 0.81$ & $10.5 \pm 2.73$ & $22.35 \pm 0.58$ & $25.82 \pm 0.57$ \\
\hline Pp30\%w & $2.71 \pm 0.67$ & $2.64 \pm 1.12$ & $2.26 \pm 0.87$ & $2.16 \pm 0.65$ \\
\hline Pp70\%w & $13.89 \pm 1.25$ & $12.34 \pm 2.67$ & $12.15 \pm 2.21$ & $14.27 \pm 1.43$ \\
\hline Pp100\%w & $17.36 \pm 2.04$ & $15.57 \pm 3.02$ & $15.07 \pm 2.17$ & $17.43 \pm 1.16$ \\
\hline Pp30\%E & $2.19 \pm 0.59$ & $2.63 \pm 1.20$ & $1.83 \pm 0.68$ & $1.97 \pm 0.86$ \\
\hline Pp70\%E & $14.91 \pm 0.31$ & $13.07 \pm 2.79$ & $12.53 \pm 1.84$ & $14.52 \pm 0.49$ \\
\hline Pp100\%E & $18.16 \pm 0.10$ & $15.6 \pm 3.48$ & $15.41 \pm 2.03$ & $17.29 \pm 0.23$ \\
\hline S. water & 0 & 0 & 0 & 0 \\
\hline
\end{tabular}

Values are mean \pm standard deviation of three replications of these concentrations of the extract

Time has highly significant effects on all species of bacteria on both Gram-negative and Gram-positive bacteria (Table 2). This means inhibitions zones of bacteria depend on exposure periods that at 24 hours it might be less inhibition, but at 48 and 72 hours, there may be more inhibition. In this study, the inhibition zones were measured against the test bacteria at 48- and 72-hours' time intervals since no more inhibitions zone was seen at 24 hours. Almost all the three solutions with three different concentrations $(30 \%, 70 \%$, and $100 \%)$ produce a higher inhibition zone after 72 hours exposure than 48 hours exposure. The $30 \%$ concentration bee collected pollen ethanolic extract showed the lower $(1.83 \pm 0.68)$ result at the time of 72 hours than 48 hours $(2.05 \pm 0.08)$ against $S$. aureus. In the study the relatively higher inhibition zone is observed against Gram-negative bacteria and Gram-positive bacteria at the time of 72 hours, this might be due to the reaction of bioactive compounds found in the solution of bee collected pollen.

\section{Discussion}

The present study summarizes bee collected pollen had high antimicrobial effects against both Gramnegative and Gram-positive bacteria, however; highly inhibition differs from species to species, working concentrations, and exposure periods. E. coli and S. boydii were more inhibited by ethanolic extract than aqueous extract and similar results were reported that different extracts exhibited different antibacterial activities(10). Ethanolic extract of pollen showed the highest inhibitions zone against both Gram-negative Loading [MathJax]/jax/output/CommonHTML/jax.js 
against all the bacteria's used(14). This study was limited to study antimicrobial activities of aqueous and ethanolic extracts against these mentioned bacteria and studying many indigenous plants' pollen antimicrobial activities against more test organisms by different concentrations of different solvent is important to find alternative solutions for resistant developing bacteria against prescribed drugs. The inhibition zones were different, according to the extraction solvent used and also pollen concentration and this result is analogs to reports of (8). Based on the solvents, used for extraction variable antimicrobial activity may be seen even against the same bacterial strains similar results were reported by (6). The results showed that bee pollen extract has an inhibitory effect against all Gram-negative and Gram-positive bacteria and similarly is reported that Turkish bee pollen extract had an inhibitory effect against all pathogens $(15,16)$. The Result Obtained from this research showed that pollen had antibacterial activity against both the Gram-Positive and Gram-Negative bacteria (Table 1,2) this is in relation with the work conducted by (14).

\section{Conclusions}

In the present research work, we concluded that the Ethanolic extract had more inhibitory effects against Gram-negative bacteria than aqueous extract. Higher concentrations of aqueous and ethanolic extracts had higher inhibitions zone than lower concentrations. Pollens might be an alternative natural food resource due to the anticipatory properties as indicated by this result. Time has significant effects against bacteria species with this p-value of $1.72 \mathrm{e}-08 * \star \star$ and treatments have significant effects with this $p$-value $\left(3.80 e^{-14}{ }^{\star \star *}\right)$. From the above table, we can conclude that ethanolic extract has significant effects than aqueous extract even though its significance effects differ based on bacteria species and exposure periods. An upcoming study is compulsory to pinpoint the functional components in a wide variety of honeybee forages' pollen and test their biological goings-on.

\section{Declarations}

\section{Acknowledgments}

First and foremost, I am obliged to acknowledge my advisors, I am very much thankful to Mr. Mosisa Daba and Tigist for their support during laboratory experimental work. It is my privilege to acknowledge Dr. Beyene Dobo for his assistance during laboratory work for critical techniques in lab work; I need to acknowledge Dr. Abiot Deddefo who was encouraging me on everything for my success and Dr. Feto Esmo Beriso general director of Oromia research institute for his help in teaching me R software that helped me to analysis my data. I need to concede my wife Dr. Zemzem Ahmed tendered her inspiration while I was editing the paper. I need to confess researcher Osho Tibesso from the USA for his fatherly advice when I was joining Hawassa University to learn my master of science and his wife Geno and my friend researcher Muhammed Abu, Dr. Musa Jarso director of Holeta agricultural research institute and finally I need to acknowledge Oromia agricultural research institute for financial support for thesis work in all aspects 


\section{Ethics approval and consent participate}

The purpose of the study was explained to Dr. Zufan Bedewi the head of the department of natural and computational science at Hawassa University, Ethiopia and she agreed to test antimicrobial activities of aqueous extract and ethanolic extract of bee collected pollen against mentioned Gram-negative and Gram-positive bacteria.

\section{Funding}

The authors would like to express their deepest gratitude to the Oromia agricultural research institute as financial support with which to conduct this research.

\section{Availability of data and materials}

The authors declare that all other data supporting the findings of this study are available within the article and its supplementary information files.

\section{Authors' contributions}

Dr. Zufan Bedewi Omer advised me as an advisor while I was doing thesis research in laboratory work to select the mentioned bacteria and laboratory produces. Mr. Kasim Roba did all laboratory work in the way Dr. Zufan commented and inserted data to Microsoft Excel and imported it to R software, analyzed, interpreted, and wrote this paper for publication, and did all necessary things. All authors have read and approved the final manuscript for publication.

\section{Consent for publication}

Not applicable.

\section{Competing interests}

The authors declare that they have no competing interests.

\section{Publisher's Note}

Springer Nature remains neutral concerning jurisdictional claims in the published paper and institutional affiliations

\section{References}

1. Kacaniova M, Vatl'ák A, Vukovic N, Petrová J, Brindza J, Nôžková J, et al. Antimicrobial Activity of Bee Collected Pollen against Clostridia. Anim Sci Biotechnol. 2014;47(2):362-5.

2. Balkanska R, Ignatova M. CHEMICAL COMPOSITION OF MULTI. FLORAL BEE POLLEN FROM. Chem Compos MULTI FLORAL BEE POLLEN FROM. 2016;(May 2014). 
3. Jamshidi-Kia F, Lorigooini Z, Amini-Choi H. Medicinal plants: History and future perspective Medicinal plants : History and future perspective. 2018;(January).

4. Kieliszek M, Piwowarek K, Kot AM. Ś AC-. Pollen and bee bread as new health-oriented products: A review Trends in Food Science \& Technology Pollen and bee bread as new health-oriented products : A review. Pollen bee bread as new Heal Prod A Rev Trends Food Sci Technol Pollen bee bread as new Heal Prod A Rev. 2018;(January).

5. Karadal F, Onmaz NE, Abay S, Yildirim Y, Al S, Tatyuz I, et al. Original article A Study of Antibacterial and Antioxidant Activities of Bee Products: Propolis, Pollen and Honey Samples.

6. Didaras NA, Karatasou K, Dimitriou TG, Amoutzias GD, Mossialos D. Antimicrobial activity of beecollected pollen and beebread: State of the art and future perspectives. Antibiotics. 2020;9(11):1-29.

7. Albaridi NA. Antibacterial Potency of Honey. 2019.

8. Dezmirean DS, Gherman B, Zacharias I. Antimicrobial Activity of Bee Pollen Ethanolic and Methanolic Extracts on Staphylococcus aureus Bacterial Strain. Antimicrob Act Bee Pollen Ethanolic Methanolic Extra Staphylococcus aureus Back Strain. 2015;(April).

9. Nutrição MEM. Maria Raphaella dos Santos Vasconcelos. 2009.

10. Al-Yousef HM, Amina M, Alqahtani AS, Alqahtani MS, Malik A, Hatshan MR, et al. Pollen Bee Aqueous Extract-Based Synthesis of Silver and Anti-Bacterial Activities. Pollen Bee Aqueous Extra Synth Silver Anti-Bacterial Act; 2020. pp. 1-12.

11. Kieliszek M, Piwowarek K, Kot AM, Ś AC-. Trends in Food Science \& Technology Pollen and bee bread as new health-oriented products: A review. Trends Food Sci Technol Pollen bee bread as new Heal Prod A Rev. 2018;71(July 2017):170-80.

12. Nascimento AMCB Jr. GEL. Bee pollen properties: uses and potential pharmacological applications-a review. Bee pollen Prop uses potential Pharmacol Appl Rev. 2019;(September 2018):2-5.

13. Gebreyohannes G, Nyerere A, Bii C, Sbhatu DB. Determination of Antimicrobial Activity of Extracts of Indigenous Wild Mushrooms against Pathogenic Organisms. Determine Antimicrob Act Extra Indig Wild Mushrooms against Pathog Org. 2019;2019.

14. Wax B. Comparative Study on the Antibacterial Activities of Bee Product (Propolis, Comparative Study on the Antibacterial Activities of Bee Product ( Propolis, Pollen, Bee Wax, and Honey). Comp Study Antibact Act Bee Prod ( Prop, Comp Study Antibact Act Bee Prod (Prop, Pollen, Bee Wax Honey ). 2018;(July).

15. Bogdanov S. Pollen. Nutrition, Functional Properties, Health. Pollen Nutr, Funct Prop, Heal. 2016; (April).

16. Campos MGR, Frigerio C, Lopes J, Bogdanov S. What is the future of Bee-Pollen ? What is the future of Bee-Pollen ? 2010;(January 2016). 